\title{
Further Observations on a Filtrable Agent Isolated from Bovine Lumpy Skin Disease
}

\author{
By M. vaN DEN ENDE aNd G. S. TURNER \\ Department of Pathology, University of Cape Town
}

SUMMARY: The method of estimating potency of lethal substances by determining death times was applied to the titration of the virus isolated from a case of bovine Lumpy Skin Disease. It was more reliable than that based on the occurrence of recognizable lesions in the embryo after amniotic inoculation.

The method was used to demonstrate the growth of virus in tissues other than skin epithelium, to determine the susceptibility of the virus to destruction by heat, and for the demonstration of neutralizing antibody.

Neutralizing antibody was found in convalescent bovine sera. Normal sera from a variety of animal species including bovines feebly neutralized the virus. This feeble neutralization may indicate the presence in sera of virus-inhibiting substances other than antibody or, in the case of bovines, antibody acquired as a result of inapparent infection.

Van den Ende, Don \& Kipps (1949) isolated a filtrable agent from skin and milk-duct nodules from a calf with Lumpy Skin Disease. The agent, which could be transmitted in fertile eggs, passed through collodion filters with average pore diameter of $53 \mathrm{~m} \mu$. Its etiological relationship to Lumpy Skin Disease in cattle could not be regarded as proved because the egg-adapted virus after twelve serial passages did not produce Lumpy Skin Disease in cattle, and the results of neutralization tests with sera from normal and convalescent animals were equivocal.

Work with this virus has continued particularly with a view to establishing its etiological role in the natural disease by neutralization tests.

The available titration method was unreliable. It depended on the development of typical lesions in chick embryos surviving for a period of 4 days after inoculation. Many deaths occurred on the second and third day after amniotic inoculation, and these, because they were not associated with recognizable lesions, had to be regarded as non-specific.

Attempts were therefore made to find a more reliable method of titrating the virus and to use it for the detection of neutralizing antibodies. The method finally adopted was also used to measure the adsorption of the virus by chickembryo tissues, and the resistance of the virus to heat.

\section{METHODS}

Material was inoculated into the amniotic cavity, chorio-allantoic cavity or yolk sac of the eggs according to the methods of Beveridge \& Burnet (1946). After incubation at $35-36^{\circ}$ the eggs were examined by transillumination once or twice a day to ascertain the time of death. In some experiments, sample eggs from each group were opened at different times after inoculation, and the membranes, as well as the embryos, carefully examined for macroscopic lesions. 
In a few instances, membranes were examined histologically. In neutralization tests, serum-virus mixtures were held at room temperature for $30 \mathrm{~min}$. and then for $\mathbf{3 0} \mathrm{min}$. in a refrigerator, before the eggs were inoculated.

For the production of antiviral serum, adult fowls received repeated intramuscular injections each of approximately one-quarter of a virus-infected chick embryo emulsified in saline. They were bled 10 days after the last of six injections and equal volumes of several sera were pooled.

\section{RESULTS}

\section{Yolk and amniotic sac inoculation}

As judged by comparative titrations (Table 1) the growth of yolk sac-adapted virus in the yolk sac was as good as the growth of the embryo-adapted virus in the embryo; but there was clearly some yolk sac adaptation because in eggs injected amniotically with embryo-adapted virus the virus content of the yolk sac was less than that in the embryo.

Table 1. The virus content of yolk sac from eggs injected with yolk sac virus after three yolk-sac passages, and of embryo from eggs infected with embryo-adapted virus

\begin{tabular}{|c|c|c|c|}
\hline \multirow[t]{2}{*}{ 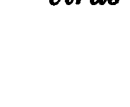 } & \multicolumn{3}{|c|}{ Dilution of virus } \\
\hline & $10^{-8}$ & $10^{-5}$ & $10^{-7}$ \\
\hline Yolk sac & 2 typical lesions, 4 dead & 5 typical lesions, 1 dead & 6 normal \\
\hline Embryo & 3 typical lesions, 3 dead & $\begin{array}{l}3 \text { typical, } 3 \text { doubtful early } \\
\text { lesions }\end{array}$ & $\begin{array}{l}5 \text { normal, } \\
1 \text { doubtful } \\
\text { lesion }\end{array}$ \\
\hline
\end{tabular}

\section{Allantoic cavity inoculation}

Attempts were made to adapt the virus to growth in the chorio-allantois rather than the amnion. Embryonic fluid from eggs inoculated by the open amniotic route was collected; when diluted 1/100 in normal saline, $0.2 \mathrm{ml}$. almost invariably killed all the embryos in 2-4 days. At first this high mortality was thought to be due to unrecognized contaminants, but it occurred regularly in spite of careful elimination of contamination and the subsequently proved absence of demonstrable bacteria.

Fluid from an embryo infected by the allantoic route, which had survived to the third day, was injected allantoically into groups of eggs, diluted in normal saline $10^{-1}-10^{-6}$. The membranes of dead eggs were examined daily, when necessary, by teasing out in saline and inspecting by darkground illumination with a hand lens. Lesions appeared inconstantly, and none was striking. Many of the membranes were thickened and in parts gelatinous. Usually there was a widespread greyish opacity, particularly in the vicinity of the blood vessels, and some membranes had innumerable tiny focal opacities. Histologically the opacities were usually composed of amorphous material which dissolved during the preparation of the section. Only occasional focal areas of cellular proliferation or infiltration were seen.

The mortality record (Table 2 ) revealed that virus multiplying in the chorio- 
Table 2. The average day of death (A.D.D.) of eggs after inoculation of virus into the allantoic cavity

\begin{tabular}{|c|c|c|c|c|c|c|c|c|c|}
\hline \multirow{2}{*}{$\begin{array}{l}\text { Dilution of } \\
\text { fluid }\end{array}$} & \multicolumn{7}{|c|}{ No. dying on (day) } & \multirow{2}{*}{$\begin{array}{l}\text { No. } \\
\text { surviving } \\
\text { on 7th } \\
\text { day }\end{array}$} & \multirow[b]{2}{*}{ A.D.D. } \\
\hline & $\mathbf{1}$ & 2 & 3 & 4 & $\mathbf{5}$ & 6 & 7 & & \\
\hline $10^{-1}$ & $1^{*}$ & 1 & 2 & 6 & - & - & - & 1 & $\mathbf{3 \cdot 3}$ \\
\hline $10^{-2}$ & - & 一 & 2 & 6 & $\mathbf{1}$ & - & - & - & $\mathbf{3 \cdot 9}$ \\
\hline $10^{-3}$ & - & $\mathbf{1}$ & 1 & $\mathbf{3}$ & 2 & 1 & 2 & 一 & 4.7 \\
\hline $10^{-4}$ & 一 & 一 & - & $\mathbf{3}$ & 5 & 2 & - & 一 & 4.9 \\
\hline $10^{-5}$ & - & - & 一 & 2 & 5 & $\mathbf{3}$ & 一 & 一 & $5 \cdot 1$ \\
\hline $10^{-6}$ & - & - & - & 1 & 1 & 1 & - & 7 & - \\
\hline
\end{tabular}

* Death regarded as non-specific and not included in calculation of A.D.D.

allantoic membranes kills with greater regularity than virus injected into the amniotic cavity, and that the time of survival of embryos increased with increasing dilution of inoculum.

Virus reached a higher titre in embryonic fluids after amniotic than after allantoic inoculation (Table 3 ). This difference persisted, though to a lesser degree, after continued serial allantoic passage.

Table 3. Comparative titrations of virus in combined amniotic and allantoic fluid of eggs inoculated either into the amniotic or allantoic space

Fluid from egg inoculated into the amniotic sac

\begin{tabular}{|c|c|c|c|c|c|c|c|c|c|c|}
\hline \multirow{2}{*}{$\begin{array}{l}\text { Dilution of } \\
\text { fluid }\end{array}$} & \multicolumn{8}{|c|}{ No. dying on (day) } & \multirow{2}{*}{$\begin{array}{l}\text { No. } \\
\text { surviving } \\
\text { on 10th } \\
\text { day }\end{array}$} & \multirow[b]{2}{*}{ A.D.D. } \\
\hline & 1 & $\mathbf{2}$ & $\mathbf{3}$ & 4 & 5 & 6 & 7 & 8 & & \\
\hline $10^{-8}$ & - & 1 & $\mathbf{3}$ & 8 & 7 & 1 & 一 & - & - & $4 \cdot 2$ \\
\hline $10^{-4}$ & $\mathbf{1}^{*}$ & $\mathbf{1}$ & $\mathbf{I}$ & 8 & 7 & 2 & 一 & - & - & $4 \cdot 4$ \\
\hline $10^{-5}$ & $\mathbf{I}^{*}$ & 1 & - & 2 & 6 & 2 & 1 & $\mathbf{3}$ & 4 & $5 \cdot 6$ \\
\hline $10^{-8}$ & $4^{*}$ & - & 一 & 2 & - & 1 & $\mathbf{1}$ & - & 12 & - \\
\hline $10^{-7}$ & - & $\mathbf{1}$ & - & $\overline{2}$ & 一 & - & - & - & 17 & - \\
\hline
\end{tabular}

Fluid from egg inoculated into chorio-allantoic sac

\begin{tabular}{|c|c|c|c|c|c|c|c|c|c|}
\hline \multirow{2}{*}{$\begin{array}{l}\text { Dilution of } \\
\text { fluid }\end{array}$} & \multicolumn{7}{|c|}{ No dying on (day) } & \multirow{2}{*}{$\begin{array}{l}\text { No. } \\
\text { surviving } \\
\text { on 10th } \\
\text { day }\end{array}$} & \multirow[b]{2}{*}{ A.D.D } \\
\hline & $\mathbf{2}$ & 4 & $\mathbf{5}$ & 6 & 7 & 8 & $\boldsymbol{9}$ & & \\
\hline $10^{-2}$ & - & 4 & 10 & 4 & 1 & 1 & - & - & $4 \cdot 7$ \\
\hline $10^{-8}$ & - & $\mathbf{1}$ & 7 & 6 & 1 & $\mathbf{2}$ & $\mathbf{1}$ & $\mathbf{2}$ & $5 \cdot 9$ \\
\hline $10^{-4}$ & - & - & $\mathbf{1}$ & $\mathbf{3}$ & 一 & - & - & 16 & - \\
\hline $10^{-5}$ & - & $\mathbf{3}$ & - & - & - & - & 一 & 17 & - \\
\hline $10^{-6}$ & 1 & - & - & $\mathbf{2}$ & 一 & 一 & - & 17 & $一$ \\
\hline
\end{tabular}

* Not included in calculation of A.D.D.

From the results in Table 3 the LD50 of virus (Reed \& Muench, 1938) in the two groups was $10^{-5 \cdot 3}$ and $10^{-3 \cdot 6}$ respectively. Furthermore, there was here also a progressive increase in survival time of eggs with increasing dilution of inoculum. This was suggestive of the results obtained by Golub (1948) for 
the titrations of psittacosis virus. A larger titration (Table 4) confirmed the relationship between average survival time and virus inoculum.

Table 4. Titration of virus in allantoic cavity

\begin{tabular}{|c|c|c|c|c|c|c|c|c|c|c|c|}
\hline \multirow{2}{*}{$\begin{array}{l}\text { Dilution } \\
\text { of fluid }\end{array}$} & \multicolumn{9}{|c|}{ No. dying on (day) } & \multirow{2}{*}{$\begin{array}{l}\text { No. } \\
\text { surviving } \\
\text { on loth } \\
\text { day }\end{array}$} & \multirow[b]{2}{*}{ A.D.D. } \\
\hline & 1 & 2 & $\mathbf{3}$ & 4 & 5 & 6 & 7 & 8 & 9 & & \\
\hline $10^{-0}$ & - & - & 6 & 8 & $\mathbf{1}$ & - & - & - & - & - & $3 \cdot 7$ \\
\hline $10^{-1}$ & - & - & 2 & $\mathbf{3}$ & 6 & 4 & - & - & - & - & 4.8 \\
\hline $10^{-2}$ & - & - & $\mathbf{2}$ & 3 & 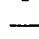 & 2 & $\mathbf{1}$ & 4 & - & $\mathbf{3}$ & $6 \cdot 1$ \\
\hline $10^{-3}$ & - & 1 & - & $\mathbf{1}$ & 4 & - & $\overline{1}$ & $\mathbf{2}$ & - & 6 & $6 \cdot 3$ \\
\hline $10^{-4}$ & $\mathbf{1}^{*}$ & - & - & - & i & 2 & 1 & - & 2 & 8 & - \\
\hline
\end{tabular}

The results recorded in Tables 3 and 4 have also been recorded graphically (Fig. 1) according to the method described by Golub. Although the values for the average day of death with different inocula are roughly linear with respect to dose in any one titration, the slopes vary with titrations, so that the average day of death after inoculation of a single, certainly fatal dose of virus could not be regarded as an accurate estimate of virus content in different fluids.

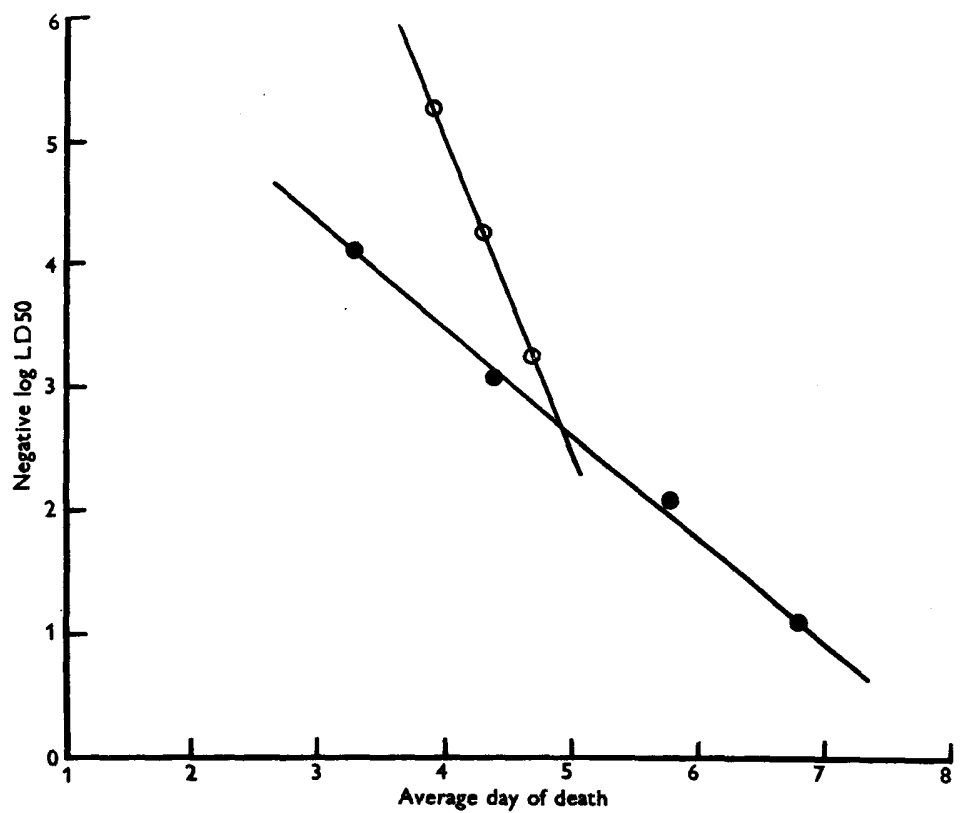

Fig. 1. Relationship between dose and death time (average day of death) of eggs receiving virus allantoically. $\mathrm{O}-\mathrm{O}$, embryonic fluids, LD50 10-4.13 (groups of fifteen eggs); - embryonic fluids, LD50 10-5.3 (groups of twenty eggs).

In all subsequent experiments virus was titrated by estimating average death times of embryos inoculated by the allantoic route. The method proved to be convenient for comparing the neutralizing potency of antisera in any one test. 


\section{Demonstration of neutralizing antibody}

In antisera. Groups of eggs received the same dose of virus mixed (a) with broth, $(b)$ with serum from fowls immunized by repeated intramuscular injections of the virus, and $(c)$ with serum from normal fowls.

There was (Table 5) a marked decrease in the mortality rate with fowl anti-serum, whereas serum from normal fowls only slightly increased the average survival time.

Table 5. Showing the virus-neutralizing power of immune fowl serum

\begin{tabular}{|c|c|c|c|c|c|c|c|c|c|c|}
\hline & & \multicolumn{7}{|c|}{ No. dying on (day) } & \multirow{2}{*}{$\begin{array}{l}\text { No. } \\
\text { surviving } \\
\text { on 10th } \\
\text { day }\end{array}$} & \multirow[b]{2}{*}{ A.D.D. } \\
\hline & & 1 & $\mathbf{2}$ & $\mathbf{3}$ & 4 & 5 & 6 & 7 & & \\
\hline & Broth & $1^{*}$ & $\mathbf{1}$ & $\mathbf{1}$ & 8 & 7 & 2 & - & - & $4 \cdot 8$ \\
\hline \multirow[t]{3}{*}{ Virus $10^{-4}$} & $\begin{array}{l}\text { Normal } \\
\text { fowl } \\
\text { serum }\end{array}$ & $1 *$ & - & $\mathbf{3}$ & 7 & 4 & $\mathbf{2}$ & 1 & $\mathbf{2}$ & $4 \cdot 5$ \\
\hline & $\begin{array}{l}\text { Immune } \\
\text { fowl } \\
\text { serum A }\end{array}$ & 一 & - & - & 一 & 1 & 1 & $\mathbf{1}$ & 17 & - \\
\hline & Broth & - & 1 & 7 & 6 & $\mathbf{1}$ & - & - & - & $\mathbf{3 \cdot 5}$ \\
\hline \multirow[t]{2}{*}{ Virus $10^{-2}$} & $\begin{array}{l}\text { Normal } \\
\text { fowl } \\
\text { serum }\end{array}$ & - & - & 2 & 9 & 4 & 一 & - & - & $4 \cdot 1$ \\
\hline & $\begin{array}{l}\text { Immune } \\
\text { fowl } \\
\text { serum B }\end{array}$ & - & 一 & - & - & - & $\mathbf{1}$ & 一 & 14 & 一 \\
\hline
\end{tabular}

In convalescent bovine sera. Table 6 shows typical results with sera supplied by The Onderstepoort Veterinary Laboratories. The sera were also tested by the orthodox method based on the inhibition of the development of lesions after amniotic inoculation. Because the number of eggs used was small the results were not analysed statistically. The neutralizing power of all the sera was relatively poor. The death-time method was no less sensitive than the other. The results illustrate the relative simplicity and ease of interpretation of the former test, the latter being complicated by the occurrence of doubtful lesions and deaths, which because of the absence of typical lesions had to be regarded as non-specific. The slight neutralization was evident both from the decrease in mortality and from the increase of average survival time, even after inoculation of serum-virus mixtures that killed all the eggs. However, with small doses of virus, interpretation was difficult owing to the slight non-specific neutralization by normal serum.

A statistical analysis was profitable only with the results with relatively large groups of eggs. These experiments (Table 7) were made with fowl anti-serum of high potency, and the purified globulin fraction from colostrum of a cow which had had Lumpy Skin Disease. The results show that dilutions of serum 
Table 6. Neutralization tests using the allantoic and amniotic routes of inoculation

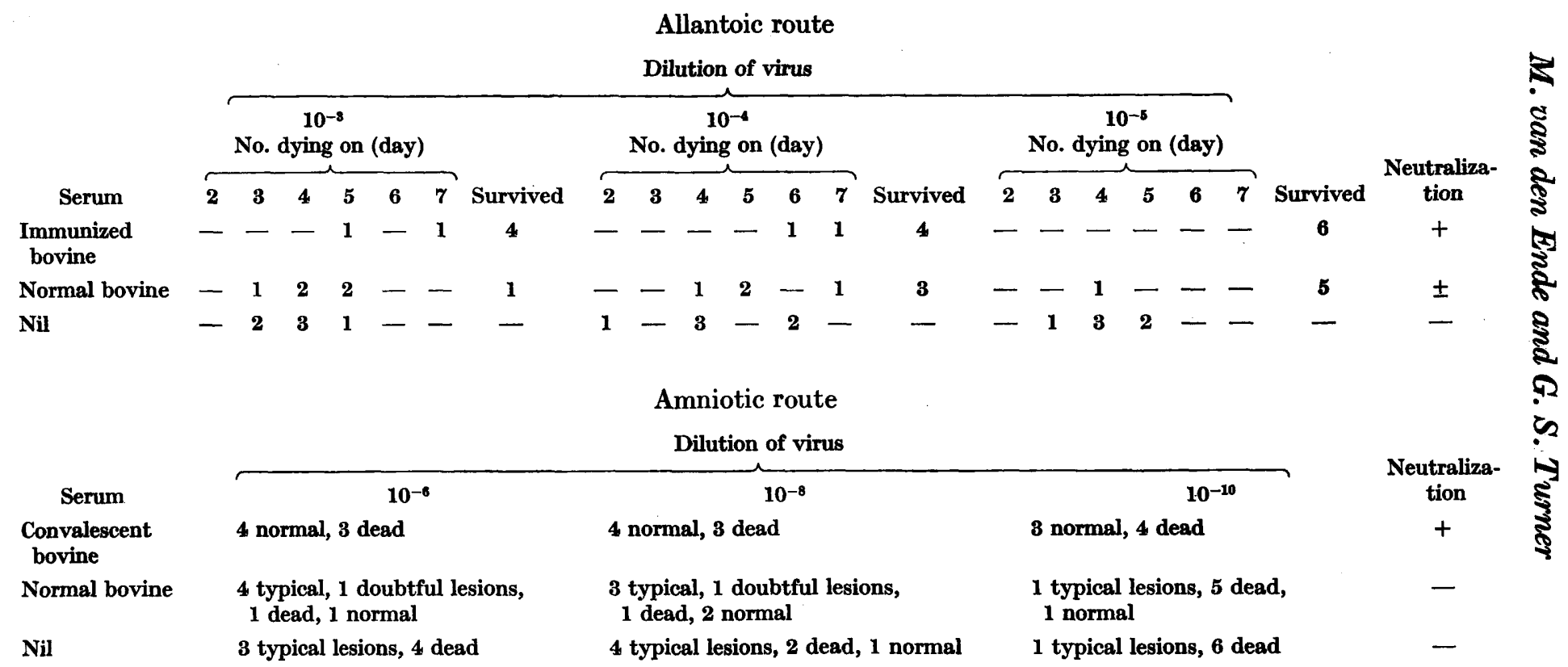




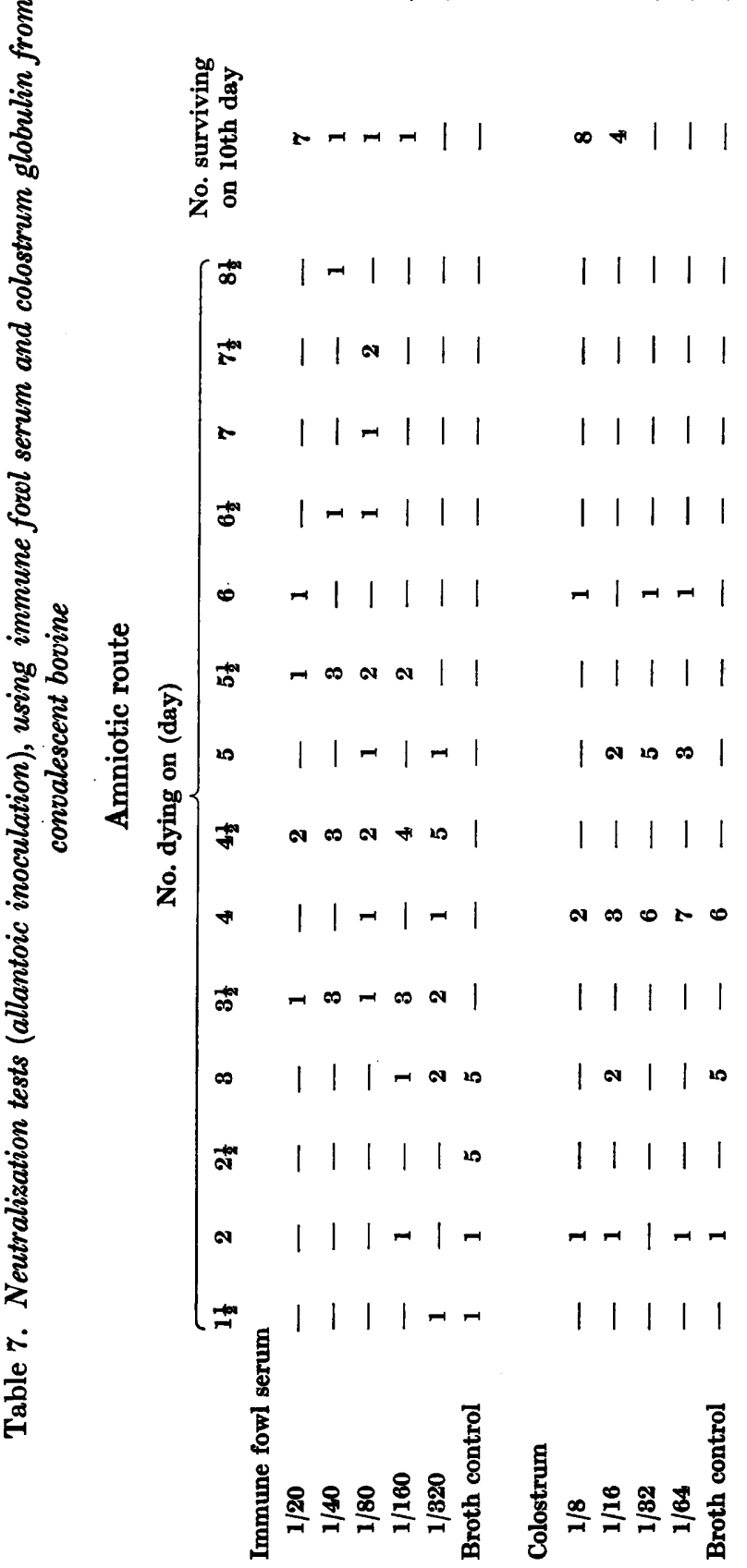


or colostrum insufficient to prevent death of any of the eggs nevertheless increased the average survival time.

It therefore appears to be sufficient in order to demonstrate neutralizing antibody qualitatively to use only one group of eggs for each serum under test. Even a ten-fold reduction in the amount of virus injected, however, increases the average survival time only very little, so that the neutralization test based on an increase in average survival time can only be reliable if large groups of eggs are used and if due allowance is made for the fact that some apparent neutralization is shown by many normal sera from a variety of animal species (Table 8).

\section{Table 8. The neutralizing power of normal sera}

\begin{tabular}{lcc} 
Broth control & \multicolumn{2}{c}{$\begin{array}{c}\text { Average day of death or } \\
\text { proportion of survivors }\end{array}$} \\
\cline { 2 - 3 } Virus $10^{-8}$ & Virus $10^{-5}$ \\
Human serum & $4 \cdot 2$ & $5 \cdot 1$ \\
Fowl serum & $4 / 10$ & $4 / 11$ \\
Guinea-pig serum & $3 \cdot 5$ & $2 / 11$ \\
& $8 \cdot 3$ & $7 / 11$
\end{tabular}

Surviving eggs were discarded after 12 days.

A large number of bovine sera were available for test, but most of them were obtained long after the animals had recovered from the disease. Furthermore, apparently normal bovines may have had subclinical infection and these sera consequently were not 'normal'. So far, striking neutralization was observed only with serum from animals that had recently recovered from the disease or had been used recently in transmission experiments. On the other hand, sera from convalescent animals were encountered in which demonstrable antibodies were scanty or absent.

\section{Absorption experiments}

The surface adsorption of a number of viruses by red blood corpuscles or tissue cells encouraged us to attempt the demonstration of similar adsorption of this virus by susceptible cells. The failure of virus suspensions to agglutinate red blood cells from a variety of animal species has already been reported (van den Ende et al. 1949).

Several attempts were made with emulsified skin from 9-day chick embryos. Skin was chosen because bovine virus is localized in the deeper layers of the skin and because the lesions in the chick embryo appeared to occur mainly in the skin or its appendages.

Skin was peeled off twelve 9-day-old chick embryos, emulsified in $10 \mathrm{ml}$. normal chick allantoic fluid containing $50 \mathrm{u}$. of penicillin and $50 \mu \mathrm{g}$. of streptomycin. The centrifuged deposit from this emulsion was thoroughly mixed with $10 \mathrm{ml}$. of a 1/20 dilution in normal fluid of allantoic fluid from a virus-infected egg, held at room temperature for $30 \mathrm{~min}$. and centrifuged. The supernatant fluid, the deposit ground up in $10 \mathrm{ml}$. normal allantoic fluid, the original virus suspension (1/20), and a control virus suspension subjected to the same centri- 
fugation as the virus-skin mixture were each tested for virus content. A single group of 10 eggs was used for each titration. The average day of death in these titrations was $4.5,5 \cdot 3,4.4$ and 4.7 respectively. There was, therefore, no demonstrable adsorption by skin tissue under the conditions of the experiment.

\section{Heat stability}

The method was also used to measure the heat stability of the virus (Table 9). The virus is completely destroyed at $80^{\circ}$ in $5 \mathrm{~min}$. Some of the virus survives $60^{\circ}$ even for $1 \mathrm{hr}$., but even $15 \mathrm{~min}$. at this temperature is sufficient to inactivate some of the virus.

\begin{tabular}{|c|c|c|c|c|c|c|c|c|c|}
\hline \multicolumn{2}{|c|}{ Heating } & \multicolumn{6}{|c|}{ No. dying on (day) } & \multirow{2}{*}{$\begin{array}{l}\text { No. } \\
\text { surviving } \\
\text { on loth } \\
\text { day }\end{array}$} & \multirow[b]{2}{*}{ A.D.D. } \\
\hline $\begin{array}{l}\text { Temp. } \\
\left({ }^{\circ} \mathrm{C.}\right)\end{array}$ & $\begin{array}{l}\text { Time } \\
\text { (min.) }\end{array}$ & 2 & $\mathbf{3}$ & 4 & 5 & 6 & 7 & & \\
\hline 100 & 5 & - & - & - & - & - & - & 10 & - \\
\hline 80 & 5 & - & - & - & - & - & - & 10 & - \\
\hline 60 & 60 & - & - & - & 2 & $\mathbf{1}$ & 2 & 5 & - \\
\hline 60 & $\mathbf{3 0}$ & - & - & 2 & 1 & 4 & - & $\mathbf{3}$ & - \\
\hline 60 & 15 & - & $\mathbf{3}$ & 5 & i & 1 & - & - & $4.0 \pm 0.6$ \\
\hline Nil & - & 1 & 9 & - & - & - & - & - & $2.9 \pm 0.2$ \\
\hline
\end{tabular}

\section{DISCUSSION}

It was clear from the outset that the proof whether or not this virus was the cause of Lumpy Skin Disease would be difficult. If the virus is the cause of the disease it must be assunaed from experiments carried out on bovines that it has lost its ability to elicit the characteristic disease in its original host. Such attentuation of animal viruses by passage through eggs is well known. Its identification must then depend on the determination of its physical and chemical properties as well as its antigenic structure.

A serious handicap in the study of this virus was the difficulty of exact titrations. The new method outlined, although itself imperfect, is simple and gives results that can be subjected to statistical analysis. A limited supply of eggs precluded the confirmation of the results recorded above, by tests designed to give statistically significant results, but it is hoped that the method will be studied in laboratories where liberal supplies of fertile eggs are available.

But even in a limited application the method proved useful in demonstrating growth in various tissues of the egg other than the skin epithelium, for which the virus at first appeared to have a special affinity. The absence of a special affinity for skin epithelium is further shown by the non-adsorption of the virus by embryo skin in vitro.

The virus can be easily adapted to growth in the allantoic cavity, causing death in 3-8 days, but without the constant production of recognizable lesions. Virus also multiplies in the yolk sac and in eggs infected by this route the characteristic skin manifestations sometimes develop in the embryo. The virus therefore appears to become rapidly generalized throughout the tissues of the egg. On the other hand, only direct inoculation into the amniotic cavity will 
regularly cause the characteristic skin and feather follicle changes previously described.

In neutralization tests sufficiently striking results have so far only been obtained with serum from immunized fowls, a sample of globulin from bovine colostrum and the occasional serum from convalescent bovines. Neutralizing antibodies in the serum of most convalescent bovines were present in relatively small amounts only.

Neutralization by the serum of apparently normal bovines at first sight might suggest that the virus has no relation to Lumpy Skin Disease, but alternative explanation is possible in the light of the known epidemiology of Lumpy Skin Disease and its behaviour in experimental animals. It is well known, for instance, that in many herds the natural disease is clinically recognizable in only a small proportion of animals. It is not unlikely that the remaining animals had experienced mild subclinical infections. This would explain the sudden disappearance of the disease from most parts of the country, and could well account for the difficulty of experimental transmission of the disease even to apparently normal animals. On the other hand, neutralization by normal serum not only from bovines, but also from man, guinea-pigs, and fowl may be the property of substances other than antibodies, and analogous to the influenza virus inhibiting substances normally encountered in serum. Substantiation of some of these arguments and proof of the identity of the virus was obtained by $\mathrm{Dr}$ R. Alexander at Onderstepoort who, in a personal communication, reports that virus after sixty-seven serial egg passages was given subcutaneously to four normal bovines bred in quarantine. Two of these developed typical generalized Lumpy Skin Disease. Why the original attempts to infect cattle with egg virus failed cannot be readily explained. The cattle used in the first attempt may have been immune in spite of not having shown clinical manifestations of previous infection. This is supported by the presence of neutralizing antibodies in the serum of apparently normal cattle. Furthermore, the virus used in the first bovine experiments was of lower titre and had been transported on its 1000-mile air journey in dry ice in which it slowly froze.

We are grateful to Mr J. H. Maytham for his assistance in carrying out this work; Dr R. Alexander and Dr A. Polson of Onderstepoort very kindly gave the colostrum globulin, many serum samples and invaluable advice.

This investigation was assisted by a financial grant from the Council for Scientific and Industrial Research for the purchase of fertile eggs.

\section{REFERENCES}

Beveridge, W. I. B. \& Burnet, F. M. (1946). The cultivation of viruses and rickettsiae in the chick embryo. Spec. Rep. Ser, med. Res. Coun., Lond., no. 256.

Ende, M. van Den, Don, P. A. \& KipPs, A. (1949). The isolation in eggs of a new filtrable agent which may be the cause of bovine Lumpy Skin Disease. J. gen. Microbiol. 3, 174.

GolUB, O. J. (1948). A single-dilution method for the estimation of L.D. 50 titres of the Psittacosis-L.G.V. group of viruses in chick embryos. J. Immunol. 59, 71.

REeD, L. J. \& Muench, H. (1938). A simple method of estimating fifty per cent endpoints. Amer. J. Hyg. 27, 498.

(Received 25 August 1949) 